\title{
THE ANALYSIS OF ISLAMIC ECONOMY IN THE CONSTITUTION OF INDONESIA
}

\author{
Siti Hamidah ${ }^{1}$, M. Bakri², A. Rahmad Budiono ${ }^{3}$, Bambang Winarno ${ }^{4}$ \\ ${ }^{1}$ Doctoral of Legal Science Program, Faculty of Law, Brawijaya University, \\ ${ }^{2}$ Faculty of Law, Brawijaya University \\ ${ }^{3}$ Faculty of Law, Brawijaya University \\ ${ }^{4}$ Faculty of Law, Brawijaya University \\ Email: hamidah@ub.ac.id
}

Submitted : 18-01-2017 | Accepted: 22-2-2017

\begin{abstract}
The development of Islamic Economy has been flourishing in the life of Indonesian people and brings impacts to several aspects of life, including in the field of law serving as the juridical basis. Indonesia is not an Islamic country. Instead, it is a constitutional country that believes in one Supreme God and protects all people to practice their religions. The sociological condition of the majority affects the formulation of law and constributes to the positive law which includes in it the issue on constitutional law.

This paper analyzes the flexibility of Indonesian's constitution in adopting and providing spaces for Islamic Economy as well as becoming the foundation for Islamic economy to fulfill the need of the society. Firstly, the analysis was conducted using theoretical approach viewed from the persepctive of the correlation between the state and religion, and the theory on legal pluralism. Further, the 1945 Constitution of State of Republic of Indonesia (UndangUndang Dasar Negara Republik Indonesia/UUD NRI 1945), was analyzed to trace the basis of Islamic economy and to develop Islamic economy based on the Indonesian's constitution.
\end{abstract}

Keyword: Islam, Economy, Constitution

\section{INTRODUCTION}

International Conference on Islamic Economy that was held in Makkah in 1976 has become the birth of Contemporer Islamic Economy. There is no doubt over the preposition that the science of Islamic Economy needs to be developed, implemented and evaluated through concepts, measurement, and standard as the product of 'Islamic Framework' that

\footnotetext{
1 Aslam Haneef, 'Islamisasi Ilmu Ekonomi, Apa yang Salah?', Thn. II No. 6/Juli-September 2005, Jurnal Islamia, 46-52.
}

involves the worldview and Islamic phylosophy. ${ }^{1}$ The development of Islamic economy has colored the life of Indonesian people and brings impacts in several aspects of life including that in the aspect of law which serves as the juridical basis for the implementation of Islamic economy.

The struggle exerted for the Islamic economy to be implemented formally has become part of every development of 
history in Indonesia. ${ }^{2}$ Feneer in his book Moslem Legal Thought in Moderm Indonesia states that the moslem leaders has since post-independence shared visions in order that Islamic Law can be implemented in the new country. In the last decade, Indonesians have been exposed with issues on law and religion, with the spotlight directed to the implementation of Islamic law or syaria in the national $\mathrm{law}^{3}$.However, some obstacles come in the way of that struggle. The first is the different views held by fellow moslems ${ }^{4}$, and the second is that the Islamic law has to deal with other values that have different principles from Islamic economy, such as the economy of capitalism.

Globalization has brought capitalims to be the winner. This ideology entered noncapitalist country via the liberalization of financial institution, the decrease of government role in economy, and extensive integration in global economic system. Malcolm Walters in Amer Al-Roubaie states that 'the rise of capitalism presents macro global dimension. Capitalism is a

\footnotetext{
${ }^{2}$ Moh. Mahfud MD, Membangun Politik Hukum, Menegakkan Konstitusi, (PTRajaGrafindo Persada, Jakarta, 2011) 265

${ }^{3}$ Nelly Van Doorn (Harder Wake Forest University), reviewing book by R. Michael Feener, Muslim Legal Thougt in Modern Indonesia, (Cambridge, Cambridge University Press, 2007) in 13-.1, 2010, Journal of American Oriental Society, 132-135.

${ }^{4}$ Caused by, among others, differences in the literal meaning and the contextual meaning from the text in Al-Qur'an or Hadits, as well as different
}

form of effective production that brings distinct feature to its disciple in the form of power. This power can be used to decrease or even eliminate the authorities of religion, politic, military, and other sources of power'. 5

The exploration on history has shown that political obstacle influences the formalization of Islamic law in Indonesia so that it can be enacted in the society. During Dutch Colonization, the political lawimplemented was the one in line with the interest of the colony through law unification in the colonized land. Receptio theory replaced Receptio in Complexu theory that served as the basis for government policies in that era. Consequently, there was conflict involving three legal systems: Islamic, traditional, and western. The conflict continues to take place up to present. $^{6}$

The majority of people in Indonesia are moslems. However, Indonesia is not an Islamic country. Instead, it is a constitutional country that believes in one Supreme God that protects each believer to

strategies in the effort of implementing in the society.

5 Waters, Malcolm, Globalization, (London, Routledge, 1995) 36, in Amer Al-Roubaie, 'Globalisasi dan Posisi Peradaban Islam', year. I No. 4/Januari-Maret 2005, Jurnal Islamia, 10-11. 6 Amrullah Ahmad, Dimensi Hukum Islam dalam Sistem Hukum Nasional, Mengenang 65 Tahun Prof. Dr. Bustanil Arifin, SH, (Gema Insani Press, Jakarta, 1996) 29. 
practice ther religion. A country which upholds law is that whose every policy is based on the law or wellknown as religious nation state. Religion becomes the esence over the law substance that is well complemented with ethics and morality. However in reality moslems, as the majority, affect the positive law. The sociological condition of the majority affects the formulation of law as well as contributing to the positive law, including constitutional law that serves as the highest law in a country and becomes the basis that is stated in UUD NKRI and Pancasila.

Islamic law posesses a good position in the context of UUD NRI 1945. It is proven in Piagam Jakarta(Jakarta Charter) that outsets the preamble of UUD NRI 1945. Even though 'seven words' previously contained in Piagam Jakarta (Jakarta Charter) have been ommited ${ }^{7}$ based on presidential decree, it still influences UUD NRI 1945 and is an unseperable part of the constitution. ${ }^{8}$

\footnotetext{
77 (seven) words located after the word "God", which were "dengan kewajiban menjalankan syariat Islam bagi pemeluk-pemeluknya"(by practicing Islamic rule for moslems). Based on Soekarno, that clause was the result of agreement from both parties, and in each agreement is based on the values of 'take and give'. However it did not take long to delete them. The meeting for amandement was based on the meeting attended by M. Hatta, Ki Bagus Hadikusumo, Wahid Hasyim, Kasman Singodemedjo and Teuku Hasan. It was the biggest gift from Moslems to Indonesia for the sake of unity of the nation. (See Hatta, Sekitar Proklamasi, page 57-59, in Endang
}

'A Living Constitution' is a statehood theory that is very popular in the United States of America. It puts argument based on necessity and aspiration in order that constitution endures and corresponds with the development. Chemerinsky states that if constitution relies merely on the intention to formulate law, that law will not be able to function to regulate modern society. ' $A$ Living Constitution is intended to 'bring constitution to life' by implementing constitutional norms in accordance with the conditions, values, and needs of the society. Further David A. Strauss articulates that constitution will always develop, change, and adapt. Constitution requires change in order to be able to survive longer. There are several ways than can be done in actualizing constitution. Among others are by formal amendment, judicial interpretation, and constitutional convention. All of them refer to one intention that is to accomodate the change in society based on the condition and changing demands. ${ }^{9}$ Consequently, the

Saifuddin Anshari, Piagam Jakarta 22 Juni 1945, Sebuah Konsensus Nasional tentang Dasar Negara Republik Indonesia (1945-1949), (Gema Insani Pers, Jakarta, 1997), 51.

${ }^{8}$ Rifyal Ka'bah, 2004, Penegakan Syariat Islam di Indonesia, (Jakarta: Khairul Bayan, 2004) 7 in Syahirul Alim (1997), above n.7, 8.

${ }^{9}$ Susi Dwi Harijanti, Menghidupkan Konstitusi Melalui Penafsiran: Perdebatan Antara Originalism dan Non-Originalism, in Penemuan Hukum Nasional dan Internasional, (Fikahati Aneska Press in cooperation with International Law Department , Faculty of Law Padjadjaran University, 2012) 584-586. 
change in society might lead to the demand of ammending the constitution.

\section{Tahir Azhary introduces Teori} Lingkaran Konsentris ( Concentric Circle Theory) through two concepts of thought. The first is the western thought which separates state-law from religion. State and law are free from the influence of religion. The second is the Islamic thought in which religion, law, and state are unseparable unity. He draw a concentrical cirle of the position of each component. State is potitioned in the outer circle, law is in the middle and religion is located in the inner most circle. State is in the outer circle and it means that state does not 'enclose' law and religion. On the religious conflict that is prevalent in Indonesia, he states that religion is not supposed to disturb the stabilityof the state and law. ${ }^{10}$

The change of the demand of the society as well as the globalization of economy affect Indonesian's constitution. This paper aims at analyzing the flexibility of Indonesian's constitution in adopting, accepting and providing place for Islamic Economy values, and find a strong base for its presence in Indonesia. It is somewhat in line with the belief held by Mochtar

\footnotetext{
${ }^{10}$ Syahirul Alim (1997), above n. 7

${ }^{11}$ CFG Sunaryati Hartono,' Upaya Menyusun Hukum Ekonomi Indonesia Pasca 2003', (Paper presented in A National development Seminar VIII with the theme of Law Enforcement in
}

Kusumaatmadja who says that one of the functions of law is to provide ways for development (politic, economy, law, and socioculture) of society. ${ }^{11}$. This paper tries to find base and ways in approaching the ideal order as contained in UUD NRI 1945 to fulfill the need of the society.

\section{LEGAL MATERIALS AND METHODS}

The legal materials of this paper are primary and secondary legal materials. Using the statute and conceptual approaches, this paper is divided into several parts. The introduction employs the approach of theory of the correlation of state and religion. It is so as Islamic economy cannot be separated from the teaching of Islam and law pluralism theory reflects the presence of two or more laws in one particular location. The following part analyzes the constitution of Indonesia, UUD NRI 1945, in tracing the basis for the existence and development of Islamic economy in the constitution of Indonesia.

\section{RESULT AND DISCUSSION}

\section{A. The Correlation between State and Religion as the Basis of the Existence of Islamic Economy}

\footnotetext{
Sustainable Development Era, held by Badan pembinaan Hukum Nasional Departemen Kehakiman dan Hak Asasi manusia, Denpasar, 14-18 Juli 20030.
} 
based on the Constitution of Indonesia.

There are several thoughts in history in regards with the correlation between state and religion in this world.The first is the thought of theocracy ${ }^{12}$ which does not separate religion and law, and that politic is the embodiment of God's direct or indirect commandment. The second is secularism which states that religion is separated from states. It includes in it the separation between the connection of men and world and the connection of men and God. Positive law is disconnected from the values of religion. In secular countries, states give freedom to their citizens to believe in religion and the state does not involve themselves in the matters of religion. The third is Communism ${ }^{13}$. Religion is human awareness before they found themselves and is considered as the fantastic realization. Therefore, religion must be suppressed, or even prohibited.

Secularism brings logical consequences toward democrazy in Western Europe. It alters the authority of God toward the people power. Constitution

\footnotetext{
${ }^{12}$ Theocracy state or state with religion is a state that puts one of the religions as the basis in the life of the nation. Some Islamic countries such as saudi Arabia, Brunei darussalam, Maroko etc claim themselves to be Islamic countries but apply different concepts. However, the similarities that they share is that they use Al-Qur'an dan hadits as the supreme constitution. See Nasaruddin Umar,Antara Negara dan Agama Negara, www.depag.go.id, no year, 2-3 .
}

has a role as a set of basic rules that frames the limit of government authority and the state accomodates the protection of human right. Therefore, in the idea of constitutionalism, constitution is not the residual fucntion of the state's authority.Instead it serves as residual function of freedom and humans rights that is handed over to the state. It indicates that the size of the authority is based on the agreement of the citizens. The demand of state's authority limitation was previously innitiated by the philosopher who tended to represent the aristocat and borguise (for example in Magna Charta 1215 or Habeas Corpus 1689 in England). ${ }^{14}$

In Islamic countries, such as in Saudi Arabia, secularism is implemented by integrating religion and state. Legislation is implemented to certain operational rules such as the law on international trade, immigration, and etc, in which the idea was first originated from the secular western countries. Legislation of rules is done by considering religious factors even though the country has gone through politic modernization and secularization along

\footnotetext{
${ }^{13}$ As one of the world ideologies, this thought was resulted from the reaction toward capitalism in the 19th century. The communism and religion is related in terms that there is a strict limitation on them atter of religion applied to the citizens. Communism believes that religion is a poison that will induce the citizens to think irrationally and unrealistically.

${ }^{14}$ Moh. Mahfud MD (2011), above n.2, .268-269.
} 
with globalization process. It is somewhat influenced by the characteristics of Islamic teaching which contains theological system of moral ethical standard and other norms of living in society. Islam does not separate sacred and profane things so that it refuses separation of state from religion. Consequently, secularism in Islamic countries does not eliminate religious orientation of the people. Even, the adoption of secular system, such as the system of democracy and the enforcement of human rights, is done by providing religious legitimation through ijtihad and some adjustments. Without this legitimation, those ideas will not get some supports. Ijtihad is part of Islamic modernization in order to keep the teaching of Islam compatible with the development of modern society without getting off track from the absolut teaching of Islam $\left(\right.$ qat $\left.^{\wedge} \hat{\imath}\right) .{ }^{15}$

In the development of secularism theory, Peter L. Berger ${ }^{16}$ refuses the theory of "secularization" and comes up with the theory of "desecularization of the world". Berger bases his thoughts on the fact that

15 Masykuri Abdillah, 'Hubungan Agama dan Negara dalam Konteks Modernisasi Politik di Era Reformasi', Volume XIII, No.2, July 2013, Jurnal Ahkam, 249.

${ }^{16}$ Berger was born in Vienna, Austria, emigrating to The United States of America after World War II. He graduated from Wagner College in 1949 with Bachelor of Arts title, and continued his study in New School for Social Research in New York (B.A in 1950, Ph.D. in 1952). He started his career in Evangelische Akademie in Bad Boll, Germany. secularism processes inflict reaction in the forms of powerful movements of countersecularization. As a result, Berger believes that modernization does bring influence on secularism but at the same time results in cntra movement called desecularism or religious fundamentalism. ${ }^{17}$

In Indonesia, the relation between state and religion is divided into two categories: antagonistic and accomodative. As a country that is not based on a certain religion and is not secular either, the concept of correlation between state and religion in Indonesia is integrated. State is not a political and religious organization. State serves as political and religious organization at the same time. Based on the symbiotic paradigm, the correlation between state and religion is perceived to be in need of one another. Religion needs the state as an instrument in preserving and developing religion. In return, the state needs religion to help it control the morality, ethic and spirituality. Religion also functionas as motivator.

In 1956-1958 and Boston College. In 1981 he earned his profesor in Sociology and Theology from Boston University, and since 1985 he had become the director of Economic Cultural Study Institute, which later known as the Institute of Culturem Religion and World Issues.

${ }^{17}$ Peter L. Berger et al., The Desecularization of the World: Resurgent Religion and World Politics, (Washington DC: Ethics and Public Policy Center, 1999) 1-4. 
Armaidyin his disertation states that there is polemic on different arguments between politicians and some citizens in regards with the correlation between state and religion. This issue needs to be analyzed for some reasons. The first is to define to what extend can a state interfere religion matters. The second is due to the emergence of some symptomps in society that reflect the western secularism. The third is related with the problem of state type contextualization in which based on the history of nation state formation Indonesia is the most pluralist country in the world. ${ }^{18}$

In the reality of politic in Indonesia,Mahfud MD states that constitutionally Indonesia is not based on religion but Pancasila. A Pancasila state is "religious nation state", or a non religiousbased as well as non secular country. Some call it as Theo-democracy. In the history,some moslem leaders have tried to find formal ways to bring Islam as the foundation of the state. The result came up that the foundation and the constitution of the state is the unity of the nation and Pancasila serves as the basis. ${ }^{19}$ In regard with the ommition of seven words from

${ }^{18}$ Armaidy Armawi, Pemikiran Filosofis Hubungan Negara dan Agama di Indonesia, summary of dissertation of Doctorate program of Philosophical Science, Master Program, Faculty of Philosophy Gadjah Mada University, Yogyakarta, 2009, pp 1-2.
Piagam Jakarta (Jakarta Charter), Moh. Hatta stated that the spirit of Piagam Djakarta did not disappear. ${ }^{20}$ In effort to implement Islamic law that is based on the current politic system, Moslems have to struggle to bring Islam becoming the frame of the political law so that the law in Indonesia can be influenced by it or if possible it can become the material of law. Consequently, Moslems should struggle and take part in the program and process of national legalization. Most importantly, Mahfud MD believes that Moslems have to struggle to make the Islamic law becomes the substantive values, not as a symbol ${ }^{21}$

The correlation between countries are reflected in the first and second principles of Pancasila. The state is based on One Supreme God,justice and civilized humanity. In the fourth main idea of the explanation on the preamble of UUD NRI 1945, Pancasila is not a secular country which separates state from religion. Article 29 chapter (1) states that the state is based on One Supreme God. Therefore, it is possible to realize Islamic economy based on constitution. Every citizen in Indoesia gets freedom to practice their religion and is protected by the nation.

\footnotetext{
${ }^{19}$ Moh. Mahfud MD (2011), above n.2, 281.

${ }^{20}$ Sekitar Proklamasi, page 69, in Endang Saifuddin Anshari, above n.7, xx.

${ }^{21}$ Moh. Mahfud MD (2011), above n.2, . 281-282.
} 
One Supreme God is a principal of Indonesia and becomes its final objective. The final objective is not only the prosperity of the people. Instead, it is One Supreme God itsself. ${ }^{22}$ The third principle that is the unity of Indonesia indicates that there is no room for conflicts of religion: among religion as well as inter and intra believers. Economic activity as a private activity in Indonesia has been familiar with pluralism in law since the Dutch colonialization era so that it is possible for Moslems to have specific rules governing economy that is adjusted with their interests.

\section{B. Law of Pluralism in Indonesian's}

\section{Economic Law}

Pluralism law has existed in Indonesia and is reflected by the divisions of citizens and law that applies to each of that division based on article 163 IS. Up to present, pluralism law still applies especially in private law. It also applies in economic law. ${ }^{23}$ The globalization from the west brings powerfull impact to economy.

\footnotetext{
${ }^{22}$ Armaidy Armawi (2009), above n. 18, 12.

${ }^{23}$ Economic law is the development of civil and trade law.it is an interdiscipliner and multidiscipliner situated between public and private laws, and a combination of dirreferent concepts of both public and private laws.

${ }^{24}$ Pluralism in law is the implementation of more than one law systems in different areas at the same time. A writing from Warwick John Tie, a senior lecturer in Massey, University of New Zealand who is interested in research on settlement of conflict in regard with this pluralism. The idea that
}

On the contrary, the needs of Moslems to live a life based on the rules of Islam needs to get attenion from the government. The implementation of two different economic laws is possible to happen in a country. ${ }^{24}$

There are substantial differences of law, culture, and civilization perceived from western and Islamic perspectives. From western perspective, culture is prone to change as response to social change. Meanwhile, civilization in Islam has been set from the very beginning. According to western point of view, Islam is part of a culture. While in Islam, culture is defined by religion. It means that Islam governs behaviour, ethical code, and moral code of human being. One of the example is that Islam provides guidance and prohibition particular deed. The freedom of human to enjoy Allah's blessings cannot go astray from the rule of Islam. Those set of rules are meant to gain happiness which includes spiritual elements that cannot be valued merely by materials because happines can only be obtained once there is a balance between world and ukhrawi..$^{25}$

came up was "law is situated within the diversity of socioculture and not upon it", the description of multicultural law surfaces from several dimensions replacing codification emphasis and power through exploration of alternative concepts based on social, democracy, and law empowerment. Read Warwick Tie, Legal Pluralism Toward a Multicultural Conception of Law, (Ashgate Publishing Company, Old Post Road, Brookfield, Vermont 05036, USA, 1999).

${ }^{25}$ Amrullah Ahmad (1996), above n.6, 21. 
Global culture spread through globalization is the western culture that is intended to distribute homogenous products and being controlled by some parties. Globalization promotes the interests of those particular parties. This culture which is characterized by materialism can inflict riot and social conflict in non-western societies which have different culture and religious lives. ${ }^{26}$ In this case, constitution should provide enough space as well as protection to citizens from conflicts triggered by globalism.

Tamanaha pays an extra attention on the importance of discussion about law pluralism. Law pluralism is not a mere absence of coordination and the presence of overlap. It instead brings the birth of authority claim due to the conflicting norms and orientation. Potential conflict will come to individuals and groups of people who fail to distinguish which law is implemented. Besides, conflict will be taken advanted from by certain people for their own interests. $^{27}$

\footnotetext{
${ }^{26}$ Waters, Malcolm (1995), above n.5,. 13-14.

${ }^{27}$ Brian Z. Tamanaha,' Understanding Legal Pluralism: Past to Present, Local to Global',v.30, 2008, Sydney Law Review, 375.

${ }^{28}$ Erman Rajagukguk,'Ilmu Hukum Indonesia: Pluralisme', (Paper presented in panel discussion on the Dies Natalis of IAIN Sunan Gunung Djati, Bandung ke-37, 2 April 2005, 2-7)

${ }^{29}$ Griffitths distinguishes pluralism into two: weak legal pluralismandstrong legal pluralism. Weak law pluralism is another form of law centralism.
}

Erman Rajagukguk says that, due to historical factors, pluralism in society and the position of Indonesia as part of global community makes it impossible for the uniform law to happen in Indonesia. The development of globalization in economy and law was started from the spices trade which brought new law to this country. At present, the economic globalization that leads to globalization in law has taken place in peace. One of the examples is by means of agreement. Therefore, there have been at least four law systems that live side by side in Indonesia lately:traditional law, Islamic law, "Civil Law" dan "Common Law." As stated in the jargon of Bineka Tunggal Ika 'diffeneces in unity', the law system in Indonesia contains pluralism. Law pluralism can boost the realization of national unity, economic development and social welfare. Those three are the biggest issues that has been faced by Indonesia. ${ }^{28}$ When analyzed based on the theory of Legal Pluralismfrom Griffiths, pluralism in Indonesia is included instrong legal pluralism, because those for systems of law have similar positions. ${ }^{29}$

Though claiming itself to hold pluralism, state law is still considered superior and other law are situtated below the state law hierarchy.Nation is a dominant law. On the contrary, a strong law pluralism concept is the product of social scientist who based their view on scientific observation on the diversity of law is all groups within society. All law systems are percieved equal in the society. There is no hierarchy which consider a particular law has higher position. Griffiths integrates the views from several experts into the law pluralism. 
The word 'agreement' shows the importance of harmonization between law systems in Indonesia. Several attempts in the harmonization of law between systems can take place by finding the similarities from both. In law, an agreement as the implementation of Islamic economy has to obey the rule of Islamic law and Civil code law. It starts from article 29 of UUD NRI 1945 1945chapter (1) "the state is based in one supreme God", and in chapter (2) "the state guarantees the freedom of its citizens to practice their religions". Therefore, Moslems have space to practice Islam including practicing economy based on Islamic teaching.

Business activity as part of muamalah is mubah or 'allowed' in Islam. It means that each moslem is allowed to do what he/she wants as long as there is no prohibition on doing from the Al Qur'an dan Sunnah". This concept has similarities with the freedom stated in article 1338 Civil Code. The freedom to make contract provides freedom to make any agreement as long as it does not contradicts with the rules. Muamalah also does the same. This harmony provides foundation for syaria financing to make agreement based on Islamic law in Indonesia by still abiding the

They are the theory of living law from Eugene Ehrlich which contains the rules of law from normative arrangements, that is made contrast with state law. John Griffiths, 'What is Legal two different systems of law, both material and substantial, the procedures, and settlement of conflict when necessary.

However, the above mentioned explanation does not mean that there is no conflict in the law pluralism in Indonesia. There are three main issues: national unity, economic growth, and social welfare. The conflict of the intention of separating themselves from the state must be settled without involving violence. That can be done by the equal distribution of economy and welfare. Besides, conflicts of race and religion can take place at anytime and anywhere. Economic growth becomes the second issue. This problem can be solved if the government provides job vacancy by opening riel sector. The third problem is how to improve the social welfare. Law must become the solution in this diverse society and plural law. $\mathrm{Tt}$ is so as law is actually a part of the development in politic, economy, social, and the philosophy of the state. In formulating the law in Indonesia, we have to consider pluralism and diverse religions, traditions, society and law systems. $^{30}$

\section{Islamic Economy in The 1945 Constitution of State of The \\ Pluralism?', n.24 1986, Journal of Legal Pluralism, 1-55. \\ ${ }^{30}$ Erman Rajagukguk (2005), above n. 28, 8-9}




\section{Republic of Indonesia (UUD NRI 1945)}

Constitution has a very broad meaning. Some definitions that are similar to the definition of institution are $L o i$ Cinstitutionnel, droit constitutionnel, Undang-undang Dasar (Basic Constitution), Qanun Asasi,Grondwet, dan staatregeling. Even in the unwritten practice, other terms surface such as unwritten constitution dan constitutional convention. However, on a daily basis the definition used is that by Brian Thompson, "a constitution is a document which containts the rules for the operation of an organization". A nation as an organization will have a manuscript called institution. ${ }^{31}$

Because constitution is the highest level of law, the objective constitution is to reach the highest goal. Those goals are:

1. justice

2. order

3. the realization of the values of freedom, prosperity and welfare

They are in line with the formulation of the objective of the nation stated by the founding fathers who formulates the constitution. ${ }^{32}$

In the formulation of UUD NRI 1945, there are explicit and implicit views and

\footnotetext{
${ }^{31}$ Jimly Asshiddiqie, 'Konstitusi Ekonomi', Kompas Media Nusantara, 2010, 3-5.
}

fundamental values. UUD NRI 1945serves not only as political constitution but also as economic constitution, and even social constitution.

The objective of the nation is stated in paragraph 4 of the preamble of UUD NRI 1945 that is , "protect the nation Indonesia, improve the social welfare, educate the nation, and participate in keeping the world in order based on the freedom, eternal peace and social welfare".

UUD NRI 1945 as a constitution does not only manage departments in the state and the governmental structure. It also rules economy and social welfare as stated in chapter 33 UUD NRI 1945. Chapter 33 of UUD NRI 1945 becomes the foundation of Pancasila's economy. Therefore, for the Islamic economy, there are two articles that are important. They are article 29 and 33.

Article 33 UUD NRI 1945 becomes the foundation of Pancasila's economic system. The economic constitution can be seen in chapter 33 :

1) Economy is built as business for all that is based on the concept of togetherness.

2) Branches for production that is important for the nation and si correlated for the social

\footnotetext{
${ }^{32}$ Ibid, 9.
} 
welfare is managed by the state.

3) Earth, water, and natural resources is managed by the state and is used fully for the welfare of the society.

4) The economy of Indonesia is practiced based on economic democracy with the principles of togetherness, justice efficiency, sustainable, environmental friendly, independent, while still maintainiing the national development and unity.

5) Further regulation on the implementation of this article is contained in the constitution.

Some important concepts that can be obtained from article 33 are: the concept of kinfolk, state suthority, social welfare, economic democracy, principle of togetherness, justice efficiency, sustainability, environmental friendly, independent, maintaining the unity of the national economy.

Article 33 and article 34 are contained in one chapter entitled National Economy and Social Welfare because both are closely

\footnotetext{
${ }^{33}$ Having Dutch educatinal background, Hatta knew exactly the weakness of capitalist economic system. though some think that Bung Hatta was
}

correlated. Article 34 governs about the poor and homeless children, social welfare system, and poor society empowerment, as well as the state's responsibility on providing health facilities.

This economic constitution must be refered to as substantial reference in making every policy throughout the process of economic development. The entire economic policy in Indonesian context must refer and must not contradict with the economic constitution, UUD NRI 1945.

Some writings state that Bung Hatta's ideas and thoughtsincredibly affect the content of Indonesian's economic constitution. ${ }^{33}$ Indonesian's eonomic constitution is based on the characteristics of Indonesian's culture as well as religion . Though in terms of the wording the its influence is not strong, it has a strong influence in terms of materail, especially that are contained in article 33 paragraph (2) and (3) stating that '(2) production branches that are important for the state and are used for the people are managed by the state. (3) Earth, water, and natural resources are managed by the state and are fully used for the welfare of the society'.

Article 33 paragraph (2) and (3) are in line with the teaching of Islam. The

affected by socialist system, the values of Islam remain strong in economic constitution. 
fundamental principal in the process of production is the economic welfare. It is somewhat similar with the principal of economy of capitalism. However Islam cannot neglect the social welfare which is related to morality, education, religion, etc. Production system in Islamic countries is defined by objective and subjective criterias. Objective criteria is reflected in the prosperity that is measured using money; subjective criteria is realized in the form of economy that conforms with AlQur'an dan Sunnah. ${ }^{34}$

Prosperity is related with ownership. Therefore, there are several types of ownership in Islam. ${ }^{35}$ They are ownership based on individual, state, and religion. As a system that stands on its own, Islam has provides explanation about the mechanism of how the ownership is obtained, how to maintain and develop the ownership as well as on how to distribute wealth among people in details through its law. Thus, the law related with Islamic economy is developed based on common norms of Islamic economy (al-qawaid al-'ammah al-

\footnotetext{
${ }^{34}$ Muhammad Abdul Mannan, Teori dan Praktek Ekonomi Islam (Dasar-dasar Ekonomi Islam), translated by M. Nastanginfrom its original title :Islamic Economic: Theory and Practice, (Dana Bhakti wakaf, Yogjakarta, 1993) 54-55

${ }^{35}$ Ownership comes from the word "Milik" that is originated from Arabic "milk" which means "is willing to act freely toward it", however, the word 'milik' can be defined as a barrier for others from doing. The word 'barrier' means prohibiting others from using and act without the permition from the owner.
}

iqtisadi al-Islamyyah) which are: ownership (al-milkiyyah), mechanism on wealth management (kayfiyyah al-tasarruf fi al-mal) and distribution of wealth among people (al-tawzi' al-tharwahbayna alnas). ${ }^{36}$

The concept of individual ownership legitimation in Islam relies heavily on morality that is correlated with social matter. Compared to socialism and capitalism, the concept of ownership in Islam has different basic thoughts. Individual ownership is the basis of capitalism, and the ommition of which becomes the main target of socialism. Islam maintains balance betwen contradicting matters. It admits individual right, but it gives quarantee over distribution of wealth through the establishment of some institutions as well as via the moral notice. ${ }^{37}$ There are some obstructions on individual ownership. For example is the interests of people ingeneral. State plays an important role in distributing health for the welfare of people. ${ }^{38}$

\footnotetext{
${ }^{36}$ A. Azhar Basyir, Garis Besar Sistem Ekonomi Islam, (Yogyakarta: BPFE, 1987).

${ }^{37}$ Muhammad Abdul Mannan (1993), above n.34. 64.

${ }^{38}$ Further Manan articulates that there are 8 provisions of Islam that manage individual wealth by: 1).utilization of beneficial , by prohibiting people posessing unused pemanfaatan kekayaan, dengan adanya larangan pemilikan kekayaan yang tidak dimanfaatkan; 2).Pembayaran zakat, yang sebanding dengan kekayaan yang dimilikinya; 3).Penggunaan kekayaan yang berfaedah, yaitu
} 
The essence of article 33 UUD NRI 1945 is based on the spirit of social, give the possesion of goods for public interest (such as natural resources) in thehand of the state. Government holds the authority in managing the life of people in Indonesia. Hence, it must posess legitimation and surveillance system. It is in line with the teaching of Islam in which being fair is obligatory. Surah al Hadiid (57:25) states that:

"Surely, We send Our prophets with real evidences and we send them the holy book and scale (justice)so that human can be just.And We created iron that has power, is great and gives benefits to human being, and so that Allah knows who help His religion and His prophets even though (Allah) does not see it. O Allah is the almighty and powerful."

There are three concrete things symbolizing the effort in maintaing unity in society; they are "holy book, scale, and iron'. Holy book refers to 'revelations' which contain command and prohibiton. Scale means justice, giving to others their rights, as well as the execution of sanction.

dipergunakan di “jalan Allah"; 4).Penggunaan yang tidak merugikan, baik bagi diri sendiri maupun orang lain; 5).Pemilikan yang sah, yaitu tidak melawan hukum; 6).Penggunaan tidak secara boros dan serakah; 7).Pemanfaatan sesuai hak; dan 8).Penerapan hukum waris yang tepat dalam Islam. Manan, ibid, 65-72.
'Iron' symbolizes power, authority, discipline, legal sanction, and etc. ${ }^{39}$

Righteousness in wealth in Islamic economy is very important. Prophet showed us the consequences of the unjust of wealth distribution in the society; at one side, abundant wealth will put faith and morality in danger, while on the other side, poverty leads the to kekufuran". So, Prophet was emphasizing on modesty. The balance of perceiving wealth is for the sake the life now and after. That is in line with statement by Prophet Muhammad: "the best among you is those who do not leave the world for the life after, and it is better for human being not to give burden of others.". ${ }^{40}$ The last word refers to independence, prosperity that is initiated from each individual. It is in line with the introduction of UUD NRI 1945.

Article 34 UUD NRI 1945 provides foundation for social welfare. The principle of compassion and protection for the poor is a universally accepted principle in Islam, and is an unseparable part of wealth distribution in which it is the obligation of the state to manage and the implementation. ${ }^{41}$ Islam organizes in details how to obtain the objectivity in fair

\footnotetext{
39 Afzalur Rahman, Doktrin Ekonomi Islam Jilid 1, Seri Ekonomi Islam No. 3, Edisi Lisensi, (Dana Bhakti Wakaf, Yogyakarta, 2005) 32-34.

${ }^{40}$ Ibid, pp. 35-37.

${ }^{41}$ Mannan (1993), above n. 37, 87.
} 
Brawijaya Law Journal Vol.4 No.1 2017

distribution of wealth, both law or option, in the forms of suggestions and prohibition. ${ }^{42}$

\section{CONCLUSION AND SUGGESTION}

Islamic economy in Indonesian constitution is possible to come into existence and develop. Based on the theory of correlation between state and religion, Indonesia is not a religious country (based on a certain religion). It is not a secular country either. By refering to the first principle of Pancasila and article 2929 UUD NRI 1945, it is the rights of Moslems in Indonesia to practice Islam including in the activity of economy, and it is the obligation of the state to assure it. The law pluralism in Indonesia is not a problem because diversity is one of the characteristics of this nation and it becomes the challenge for the nation to solve this issue.

Article 33 UUD NRI 1945 is the economic constitution in Indonesia that owns Islamic economy values which have to conform with three rules of economy, they are: ownership (al-milkiyyah), mechanism of wealth management (kayfiyyah al-tasarruf fi al-mal) and distribution of wealth among human beings (al-tawzi' al-tharwahbayna al-nas).
Constitutional Issues and Indigenous Rights

\section{REFERENCES}

\section{Journal Articles}

Aslam Haneef, 'Islamisasi Ilmu Ekonomi, Apa yang Salah?', Thn. II No. 6/JuliSeptember 2005, Jurnal Islamia

Amer Al-Roubaie, 'Globalisasi dan Posisi Peradaban Islam', Thn. I No. 4/Januari-Maret 2005, Jurnal Islama

Brian Z. Tamanaha, 'Understanding Legal Pluralism: Past to Present, Local to Global', Vol. 30, 2008, Sydney Law Review, 375-411

John Griffiths, 'What is Legal Pluralism?', n. 24, 1986, Journal of Legal Pluralism, 1-55

Masykuri Abdillah, 'Hubungan Agama dan Negara dalam Konteks Modernisasi Politik di Era Reformasi', Volume XIII, No.2, Juli 2013, Jurnal Ahkam, 247-258

\section{Books}

A Azhar Basyir, Garis Besar Sistem Ekonomi Islam, (Yogyakarta: BPFE, 1987)

Afzalur Rahman, Doktrin Ekonomi Islam Jilid 1, Seri Ekonomi Islam No. 3, Edisi Lisensi, (Dana Bhakti Wakaf, Yogyakarta, 2005)

\footnotetext{
${ }^{42}$ Afzalur Rahman (2005), above n. 39, 98.
} 


\section{Doktrin Ekonomi Islam}

Jilid 2, Seri Ekonomi Islam No. 3, Edisi Lisensi, (Dana Bhakti Wakaf, Yogyakarta, 2005)

Amrullah Ahmad, Dimensi Hukum Islam dalam Sistem Hukum Nasional, Mengenang 65 Tahun Prof. Dr. Bustanil Arifin, SH, (Gema Insani Press, Jakarta,1996)

Armaidy Armawi, Pemikiran Filosofis Hubungan Negara dan Agama di Indonesia, Ringkasan Disertasi Program Doktor Ilmu Filsafat, Pascasarjana Fakultas Filsafat, Universitas Gadjah Mada, Yogyakarta, 2009.

Endang Saifuddin Anshari, Piagam Jakarta 22 Juni 1945, Sebuah Konsensus Nasional tentang Dasar Negara Republik Indonesia (1945-1949), (Gema Insani Pers, Jakarta, 1997)

Moh. Mahfud MD, Membangun Politik Hukum, Menegakkan Konstitusi, (PT RajaGrafindo Persada, Jakarta, 2011)

Muhammad Abdul Mannan, Teori dan Praktek Ekonomi Islam (Dasardasar Ekonomi Islam), diterjemahkan oleh M. Nastangin, Judul Asli: Islamic Economic: Theory and Practice, (Dana Bhakti wakaf, Yogjakarta, 1993)
Muhammad Tahir Azhary, Negara Hukum: Suatu Studi Tentang Prinsip Prinsipnya Dilihat dari Segi Hukum Islam, Impementasinya pada Periode Negara Madinah dan Masa Kini, (Jakarta, Kencana, 2007)

Peter L. Berger et al., The Desecularization of the World:Resurgent Religion and World Politics, (Washington DC: Ethics and Public Policy Center, 1999)

Susi Dwi Harijanti, Menghidupkan Konstitusi Melalui Penafsiran: Perdebatan Antara Originalism dan Non-Originalism, dalam Penemuan Hukum Nasional dan Internasional, (Penerbit Fikahati Aneska bekerjasama dengan Bagian Hukum Internasional, Fakultas Hukum Universitas Padjadjaran, 2012)

Syahirul Alim, Sejarah dan Konsep Pembaruan Hukum Islam Masa Kini di Indonesia, (Web Direktorat Jendral Badan Peradilan Agama Mahkamah Agung Republik Indonesia)

Warwick Tie, Legal Pluralism Toward a Multicultural Conception of Law, (Ashgate Publishing Company, Old Post Road, Brookfield, Vermont 05036, USA, 1999) 
Brawijaya Law Journal Vol.4 No.1 2017

\section{Conference Paper}

CFG Sunaryati Hartono, 'Upaya Menyusun

Hukum Ekonomi Indonesia Pasca 2003', (Paper presented at Seminar pembangunan Nasional VIII dengan tema Penegakan Hukum dalam Era Pembangunan Berkelanjutan, diselenggarakan oleh Badan pembinaan Hukum Nasional Departemen Kehakimam dan Hak Asasi manusia, Denpasar, 14-18 Juli 2003)

Erman Rajagukguk, 'Ilmu Hukum Indonesia: Pluralisme', (Paper presented at Diskusi Panel dalam rangka Dies Natalis IAIN Sunan Gunung Djati, Bandung ke-37, 2 April 2005)
Constitutional Issues and Indigenous Rights

Jimly Asshiddiqie, Konstitusi Ekonomi, (Kompas Media Nusantara, Jakarta, 2010)

Muhammad Alim, 'Asas-azas Hukum Modern dan Pengujian Peraturan Dalam Islam', (Paper presented at Kuliah Umum Fakultas Hukum Universitas Muhammadiyah Yogyakarta, 2002)

Nasaruddin Umar, 'Antara Negara dan Agama Negara', www.depag.go.id, tanpa tahun , diakses tanggal 11 Januari 2015, pukul 15.50.

Act

Undang Undang Dasar Negara Kesatuan Republik Indonesia 1945 
